\title{
0 tratamento xurisprudencial dos dereitos da personalidade en chave de xénero
}

https://doi.org/10.21814/uminho.ed.30.16

\author{
Julia Ammerman Yebra \\ Doutora en Dereito Civil pola \\ Universidade de Santiago de Compostela
}

\section{Introducción}

No ordenamento xurídico español, os dereitos da personalidade aparecen regulados no art. 18.1 da Constitución, e na Lei Orgánica 1/1982, de protección civil do dereito á honra, á intimidade personal e familiar e á propia imaxe. Este precepto aparece numerosas veces invocado perante os tribunais, chegando moitos casos ata a sala primeira do Tribunal Supremo (Sala do Civil) e ata o Tribunal Constitucional. Facendo un percorrido por estes casos dende antes da promulgación da LO 1/1982, apreciamos que nin a casuística dos concretos dereitos da personalidade invocados é a mesma cando o dereito vulnerado pertence a un home ou a unha muller, nin o razonamento ó que chegan ós membros destes dous altos tribunais (ambos compostos maioritariamente por homes) segue as mesmas pautas nuns casos e noutros.

Así, por unha banda, temos observado que as mulleres deben facer fronte en moitas máis ocasións ás intromisións na súa vida privada ou a usos da súa imaxe, usualmente cunha carga sexual ou de consumo, mentres que os homes tratarán de protexer sobre todo violacións que teñan que ver coa súa vida profesional ou estima social. Esta situación cremos que xurde xa cos primeiros casos de protección da personalidade que se dan tanto en Europa como en EEUU a finais do século XIX, polo que será por este extremo polo que debamos comezar a nosa análise.

\section{Perspectiva histórica da xurisprudencia sobre dereitos de imaxe no dereito comparado}

Comezando por Francia, o caso Rachel, de $1858^{1}$, é o que se considerou tradicionalmente que dá nacemento ao dereito á propia imaxe. Nel, a famosa actriz francesa da época Elisabeth Fénix (Rachel) foi retratada no seu leito de morte mediante un debuxo a lapis realizado, a pedimento dos seus familiares, por un fotógrafo, e cuxo único fin era preservar o debuxo como memoria privada da familia. Cando posteriormente apareceu

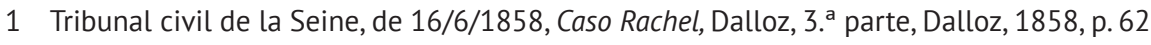


o retrato nun xornal, a familia demandouno e o Tribunal civil da Seine sentenciou a favor da familia, argumentando que ninguén podía reproducir e distribuír publicamente os trazos dunha persoa no seu leito de morte sen o expreso consentimento dos familiares, independentemente de que a retratada fose famosa e de que en vida fixese públicos moitos dos seus actos. Declarou como absoluto o dereito para opoñerse á reprodución, dereito que tiña o seu fundamento no respecto á dor da familia, que en caso contrario vería vulnerados os seus sentimentos máis íntimos.

Máis coñecido é o caso de Sarah Bernhardt² famosa actriz da época que dera permiso para que un coñecido perfumero comercializase unha fragrancia baixo o seu nome e co seu retrato no envoltorio. Outro comerciante de perfumes procedeu de igual modo, pero sen o permiso da artista. Curiosamente, non é ela a que expuxo a demanda, senón o perfumero autorizado. Tanto en primeira instancia como en apelación desestímase a petición sobre a base de que só a actriz e o autor da fotografía estarían lexitimados para demandar. Ademais, tamén se argumenta que o perfumero non tería a titularidade exclusiva nin do nome nin da fotografía (Sarah aceptara "con gran pracer ser a madriña dese perfume marabilloso", pero nada se dicía sobre que non podía ceder o seu nome e imaxe a outros).

En Italia tamén se deron casos similares aos comentados a finais do século XIX e comezos do século XX. Nun deles comercializáronse postais coa imaxe dunha coñecida cantante sen o seu consentimento, sentenciando o tribunal que é un acto ilícito, que causa un dano á artista xa que a persoa posúe "libéraa ed esclusiva disposizione do proprio aspetto" 3 .

En Alemaña un dos primeiros litixios coñecidos foi o resolto polo Reichsgericht, sala do penal, en 1898, no que unha muller foi fotografada, ás agachadas, cando estaba con roupa de baño. As fotografías foron utilizadas nuns pisapapeles destinados á venda e, tras a denuncia da muller, o tribunal dispuxo que os feitos eran constitutivos dun delito de difamación porque os potenciais compradores do pisapapeles asumirían que a muller pousara voluntariamente para as fotografías ${ }^{4}$.

Finalmente, no Dereito anglosaxón tamén atopamos varios litixios sobre vulneración dos dereitos de imaxe entre finais do século XIX e comezos do XX. En 1890 o caso de Marion Manola, famosa actriz da época, foi coñecido en todo EEUU ${ }^{5}$. Ela negouse a que lle realizasen fotografías durante unha función - unha ópera cómica na que era a protagonista- por aparecer vestida con roupa lixeira e medias, e aínda que fixo público este desexo, durante unha función apreciáronse varios flashes. Demandada a compañía, e aínda que as fotografías nunca saíron á luz, o tribunal de Nova York ditou un preliminary injunction contra o uso das mesmas.

2 Tribunal comm. Seine 8/6/1886, Annales de la propriété industrielle, 1894, pp. 349-353.

3 Trib. Civ. De Milano 27 de maio de 1903, Giurisprudenza italiana, 1903, I, pp. 713-716.

4 RGSt 29/11/1898, caso recollido por GÖTTING, Horst Peter, Persönlichkeitsrechte als Vermögensrechte, Mohr Siebeck, Tübingen, 1995, p. 18, nota 30.

5 Marion Manola v. Stevens \& Myers, N.Y. Supreme Court, “New York Times” June 15, 18, 21, 1890. 
En 1902, a Corte de Apelacións de Nova York tivo que decidir sobre un caso, Roberson v. Rochester Folding Box Co. no que o rostro da "nova e atractiva" Abigail Roberson fora utilizado sen o seu consentimento para protagonizar un anuncio de fariña, co lema "Fariña da familia" ("Flour of the Family") $)^{6}$ que tivera alcance tanto local (o que máis dano fixo a Abigail, xa que a recoñeceron os seus achegados) como internacional. Iso xeroulle crises nerviosas que requiriron de tratamento, e solicitou na demanda 15.000 dólares polos danos sufridos e a prohibición de que se continuase utilizando a súa imaxe na publicidade. 0 tribunal ditaminou que a súa imaxe, "debido á súa beleza", tiña un gran valor como marca ou como recurso publicitario, polo que constituía "un dereito de propiedade que só a ela pertencía", pero finalmente decidiu, por catro votos fronte a tres, que o "Right to privacy" aínda non tiña acomodo na xurisprudencia norteamericana, pois preocupaban os cotos que podía supoñer á liberdade de expresión. A resolución non tivo boa acollida entre o público xeral, e mesmo xerou que un dos xuíces do tribunal escribise meses máis tarde un artigo doutrinal no que se defendía da opinión popular ${ }^{7}$. En definitiva, unha porcentaxe moi alta dos primeiros casos nos que se aprecian intromisións ilexítimas nos dereitos de imaxe teñen como protagonistas ás mulleres, branco prioritario das novas cámaras fotográficas. Isto, como vimos, foi unha constante tanto en Francia, primeiro país do que temos constancia dun caso de dereitos de imaxe, como en Italia e Alemaña, con varios casos coñecidos e, notablemente, en Estados Unidos. De feito, nos anuncios estadounidenses daquela época dunha coñecida marca de cámaras fotográficas reforzábase a idea de masculinidade dos fotógrafos mostrando a homes cazando ou viaxando, a miúdo mediante analogías entre os disparos dunha arma e os dunha cámara. Outra empresa fotográfica anunciaba unha nova patente de cámaras "detectivescas" - nas que a imaxe tomada correspondía aos suxeitos situados no ángulo dereito onde aparentemente apuntaba a cámara, e non á fronte como sería de supoñer-, coa representación dun fotógrafo (home), e dúas mulleres situadas no ángulo ditoso, que non se decataban de que estaban a ser fotografadas. Este e outros exemplos serven de base no Dereito estadounidense para explicar, por parte dun sector doutrinal ${ }^{8}$, o nacemento do Right to Privacy (en cuxo concepto se engloban tamén os dereitos de imaxe) en clave de xénero, como mecanismo de protección das imaxes das mulleres. Neste sentido,

\footnotetext{
6 Os anunciantes están xogando coa pronunciación de "Flour" (fariña en inglés), xa que é a mesma que para "Flower" (flor en inglés). Polo que a frase podería entenderse como "Flor da familia", representando Abigail Roberson esa "flor".

7 O xuíz foi Denis O’Brien, quen escribiu "The Right of Privacy" no Columbia Law Review de Novembro de 1902, opinando na p. 438 que cando "un xornal [The New York Times] xeralmente tan xusto e razoable nas discusións sobre cuestións públicas, daba unha idea tan desafortunada do que realmente dicía a sentenza, á vez de errónea (...) debíase aceptar que o xornalismo non sempre era unha guía segura (...) para analizar o alcance e efecto das decisións xudiciais". O certo é que a opinión tanto deste xuíz como do relator resultan un tanto hipócritas, sobre todo a deste último, pois un ano despois de ditada a sentenza, e con motivo da súa presentación como candidato á presidencia, emitiu un comunicado á prensa dicindo que non ía tolerar fotografías e xornalistas omnipresentes que captasen calquera momento da súa vida ou da da súa familia, ao que Abigail Roberson respondeu nunha carta ao New York Times titulada "Paker Taken to Task by an Indignant Woman - If I Can Be Photographed, Why Not You? Ask Miss Roberson”, 27 July 1904.

8 LAKE, Jessica, The Face That Launched a Thousand Lawsuits. The American Women who Forged a Right to Privacy, Yale University Press, Connecticut, 2016.
} 
a doutrina postula que, aínda que WARREN e BRANDEIS non consideraron o tema como algo feminino, os debates que lles levaron a escribir o seu famoso artigo "The Right to Privacy" eran sobre como protexer ás "señoritas" que eran fotografadas sen o seu consentimento. Mesmo chegou o tema, en 1885, a tocar á Primeira Dama de entón, pois tras a celebración do seu matrimonio co presidente de EEUU, a súa imaxe comezou a aparecer en todo tipo de anuncios publicitarios, desde xabóns ata tabaco e pianos. Iso xerou que se tratase de aprobar unha lei, "A Bill to Protect Ladies", que prohibise utilizar as imaxes das mulleres sen o seu consentimento nos anuncios. No preámbulo da lei dicíase que o propósito da mesma era prohibir o uso da imaxe de mulleres con fins propagandísticos por ser as esposas, fillas, nais ou irmás de cidadáns americanos, e quen o fixese incorrería en falta grave e debería pagar unha multa de entre $\$ 500$ e $\$ 5000$. Nótese que se supeditaba a protección para ser as "esposas de", "fillas de", etc., claro exemplo de que as mulleres non eran cidadás de pleno Dereito, pero protexíallas en tanto que estivesen sometidas a un home, o que leva tamén á conclusión de que o obxectivo non era só protexer a imaxe da muller, senón máis ben a reputación ou honra do home con quen tiña un vínculo familiar.

Finalmente, e debido á oposición dos fotógrafos (na súa maioría, homes), nunca chegou a aprobarse a lei. Pero pouco despois, en 1902, a Corte de Apelacións de Nova York tivo que decidir sobre o caso Roberson v. Rochester Folding Box Co. ${ }^{9}$, no que, aínda que a muller non conseguiu que se lle recoñecese ningún dereito, o caso si favoreceu a que se aprobasen as primeiras leis de EEUU sobre protección da privacidade. Segundo LAKE, as mulleres como Abigail Roberson empezaron a usar o concepto de Right to Privacy como instrumento para cuestionar as prerrogativas masculinas dos dereitos de copyright, argumentando que o valor contido nun "bonito retrato" estaba tanto no rostro da persoa como no papel sobre o que se imprimía.Así, di a autora que o Right to Privacy enténdese mellor como parte da loita das mulleres por alcanzar os dereitos cidadáns ao comezo do s. XX.

\section{Perspectiva histórica da xurisprudencia sobre o dereito á honra no dereito español}

Se ben non nos constan sentenzas protexendo o dereito a imaxe no caso español entre finais do século XIX e comezos do XX, o que si que atopamos a partir da segunda década do século XX é unha protección do dereito á honra que non é igual dependendo de se estamos ante a honra dun home ou ante a dunha muller. Esta diferente concepción da honra, segundo estivésemos ante deshonras -ou intromisións no dereito á honra, en terminoloxía actual-, de homes ou mulleres, xa se pode apreciar nas fontes anteriores, por exemplo cando as Leis de Partidas establecían unha concepción da honra das mulleres que recollía básicamente a moral sexual da

9 Roberson v. Rochester Folding Box Co., 65 NYS 1109. 
época, e por outra banda unha idea de honra dos homes como cualidade caballeresca ou heroica ${ }^{10}$.

Como dicimos, o diverso tratamento do dereito á honra continuou nos séculos vindeiros, e cremos que se aprecia claramente nas primeiras sentenzas que recollen unha protección civil da honra das persoas no noso ordenamento. Empezando pola coñecida sentenza do Tribunal Supremo do 6 de decembro de $1912^{11}$, os danos morais que se conceden, por vez primeira, no noso ordenamento son precisamente a causa do dano á "honra dunha doncela". A deshonra viña dada pola difusión no xornal $O$ Liberal da falsa noticia do rapto dunha "bellísima señorita" de quince anos por parte dun frade, "de quen xa tivera escandalosa sucesión tres meses antes", e que tras ser descuberto se suicida. Aínda que o xornal se desdixo tras recibir un telegrama do corresponsal de Totana, concello onde acontecían os feitos e que se mostraba indignado "contra a infame noticia dada por outros individuos contra o bo nome de persoas prestixiosas", o pai da menor, por certo alcalde do citado municipio, interpuxo unha demanda contra o xornal pedindo unha indemnización de 150.000 pesetas polo dano inflixido "á honra dunha doncela por culpa ou neglixencia civil". Aínda que non negamos as boas intencións do pai, a circunstancia de que o mesmo fose alcalde, sumado ao devandito polo citado corresponsal de que se atentaba contra "o bo nome de persoas prestixiosas", fainos pensar que moi seguramente tamén se estaba tratando de protexer a honra do rexedor, cuxo cargo podería verse comprometido con tales feitos.

Tras esta citadísima sentenza promulgáronse outras, tamén do Tribunal Supremo, que tiveron por obxecto a protección da "honra ou da boa fama", como dicía DE CASTRO. Así, este autor recolle, á vez do de 1912, outro caso do 12 de marzo de 1928 sobre a honra e bo nome dunha rapariga; e por outra banda, os casos do 14 de decembro de 1917, no que se protexeu "a fama e reputación profesional dun médico", e outros sobre "o crédito e boa fama dun comerciante" (SSTS do 31 de marzo de 1930, 25 de xuño de 1945, 27 de febreiro de 1959 e 7 de febreiro de 1962) ${ }^{12}$. Como se aprecia, estamos ante criterios diferentes á hora de medir a honorabilidade das persoas: mentres que no primeiro e feminino os criterios son exclusivamente referidos á moral sexual imperante na época (e que aínda hoxe non conseguiu erradicarse), os segundos e masculinos refírense á reputación profesional do agraviado.

10 Para afondar na diferente concepción da honra na Idade Media, vid. AMMERMAN YEBRA, Julia, A bill to protect ladies: los derechos de la personalidad desde una perspectiva feminista, "Mujer como motor de innovación jurídica y social”, TOMÁS, Gema / VIDU, Ana (Coord.), Tirant lo Blanch, Valencia, 2021, pp. 57-72.

11 Recollida por DE CASTRO Y BRAVO, Federico, Los llamados derechos de la personalidad, "Anuario de Derecho civil", Vol. 12, núm. 4, 1959, pp. 1269-1271.

12 DE CASTRO Y BRAVO, Federico, Temas de Derecho Civil, Marisal, Madrid, 1972, p. 18. 0 autor tamén menciona outras dúas sentencias nas que non podemos apreciar se estamos ante a honra dun home ou dunha muller, pois refírese á "difamación nun periódico e á reparación debida á familia" (STS de 7 de novembro de 1919) e á "querella criminal inxustificada" (SSTS de 13 de xuño de 1950 e de 7 de febreiro de 1962). 


\section{O tratamento xurisprudencial do dereito á honra e á imaxe por parte dos tribunais españois na actualidade}

Tomando como punto de partida o ano 1982, por promulgarse en maio dese ano a LO $1 / 1982$, realizamos un varrido polas Sentenzas do Tribunal Constitucional e da Sala Primeira do Tribunal Supremo desde entón e ata hoxe, ditadas en materia de dereitos de imaxe (introducindo o criterio "dereito á imaxe" na base de datos Westlaw-Aranzadi), así como dereitos de honra e intimidade cando estes gardan relación con aquel. Grosso modo podemos dicir que foron case medio centenar as sentenzas que versaban sobre divulgacións inconsentidas de imaxes de mulleres. Delas, a metade correspondíanse a imaxes nas que se apreciaban partes íntimas do seu corpo por ser tomadas en praias ou en lugares privados. En cambio, son menos de media ducia as sentenzas nas que se condenan vulneracións do dereito á propia imaxe de homes en bañador ou mostrando partes íntimas do seu corpo, e só dous nas que se ve violado este dereito por tomarse as fotografías en lugar privado ou por modificar a imaxe dun ciclista profesional ${ }^{13}$.

Tras a análise xurisprudencial anterior, apréciase como son as mulleres as que en moitas máis ocasións deben facer fronte a intromisións na súa vida privada ou a usos da súa imaxe cunha carga sexual, erótica ou de consumo, cousa que sucede en moita menor medida coas imaxes dos homes, que no que se refire a dereitos da personalidade alegarán fundamentalmente vulneracións da súa honra ou reputación, é dicir, a cuestións que teñen que ver coa súa vida profesional ou a súa estima social, pero non tanto coa súa intimidade ou imaxe. Así, mentres que os homes preocuparanse máis por controlar a información divulgada sobre a súa persoa, as mulleres terán que protexerse en maior medida de violacións á súa imaxe, á súa integridade e, en definitiva, á súa dignidade como mulleres. Na nosa opinión, os dereitos á honra e á propia imaxe non deberían ter significados ou connotacións diferentes segundo estemos ante un home ou unha muller; polo que esperamos que esta denuncia dos sesgos de xénero que todavía seguen presentes na xurisprudencia española, contribúan dalgunha maneira a erradicalos.

13 Pode consultarse a relación de sentencias en AMMERMAN YEBRA, Julia, A bill... op.cit., pp. 70-71. 